\title{
Online Purchase Intention for Baby Products in Indian context using Linear Programming Models
}

\author{
${ }^{1}$ E.Pradeep, ${ }^{2}$ Dr.V.M.Shenbagaraman and ${ }^{3}$ Dr.P.Saravanan \\ ${ }^{1}$ Assistant Professor, Faculty of Management, SRM Institute of Science and Technology, Kattankulathur, Chennai \\ ${ }^{2}$ Professor, Faculty of Management, SRM Institute of Science and Technology, Kattankulathur, Chennai \\ ${ }^{3}$ Assistant Professor, Faculty of Management, SRM Institute of Science and Technology, Kattankulathur, Chennai
}

Correspondence Author: E.Pradeep, Assistant Professor, Faculty of Management, SRM Institute of Science and Technology, Kattankulathur, Chennai E-mail: Pradeep.e@ktr.srmuniv.ac.in

Received date: April 2018, Accepted date: 28 July 2018, Online date: 5 August 2018

Copyright: (c) 2018 E.Pradeep, et al., This is an open-access article distributed under the terms of the Creative Commons Attribution License, which permits unrestricted use, distribution, and reproduction in any medium, provided the original author and source are credited.

\begin{abstract}
In the current scenario, the customers are giving more importance on the purchase of any products. But when it comes to baby products, the customers or particularly parents are very much keen on the quality of the product, hygiene and safety of the products. Now the companies are also developing the products with the latest cutting edge concerning the safety of the product. The retailers are in India are trying to provide the best products to the customers. The customers will look into various factors very seriously when they are purchasing the baby products. They go with the word of mouth; they browse into the website, they see for the product reviews, consumer reports, etc. before purchasing the baby products. This research paper reveals the purchase intention of the baby products and the factors that really influence to purchase the products. The paper shows simulation modelling on the purchase intention of the baby products.
\end{abstract}

Key words: Purchase intention, Baby products, simulation modelling, consumer behaviour, quality and safety, Retailing

$$
1
$$

\section{INTRODUCTION}

As baby products are very important, keeping in mind the end users of the products who are highly sensitive and extremely tender, there is a huge demand for high quality baby products and their sales has been increasing day to day. All items related to baby care like baby toys, baby food, baby skin and hair care, baby furniture are all included in the baby products segment. According to RNCOS report, 'The market for Indian baby products segment has increased tremendously, during 2015, due to the widespread awareness of standard and high quality baby care products, increasing incomes of the household due to rising working population and a huge surge in the number of nuclear families'. They have also added that the Indian baby products segment is still in the developing phase and undergoing continuous transformations. Also it is anticipated that this sector will clock in a CAGR of more than $15 \%$ during the period $2015-2022$.

According to another famous source Mintel Global New Products Database (GNPD), the number of new products launched in the beauty and personal care segment in India, for babies and toddlers has almost doubled between 2015 and '16. Earlier baby products predominantly meant shampoos and massaging oils. Now this category encompasses baby wipes, specialised skin and hair products suited according to the mildness of babies' skin. For example, Himalaya has now expanded its product mix from shampoos, oils and creams to diapers and wipes. Another instance is, Hindustan Unilever's Baby Dove has entered into the baby products segment ranging from soap bars, diaper rash creams, lotions to baby wipes. According to the Census, households with more than five members increased by $12 \%$ between 2001 and 2011, whereas households with three to four members drastically increased by 53\%, indicating a paradigm shift towards living in nuclear families. The buying behaviour of consumers keeps on changing due to varied factors and these will, in turn, influence the sales of the product. Each and every person or family has a different buying behaviour suiting to their tastes, needs and interests.

\section{Review of Literature:}

Purchase decisions depend upon quality and brand value for infant and follow-up formula feeds and price is not a concern for them (Yee and Chin, 2017). Choosing the right brand among the various available brands is the most challenging task. (Daniels, 2009). It is highly essential to identify the needs of various customers and satisfy them. (Mathuthra and Latha, 2016). Baby accessories are chosen with the brand's perception and equity and they studied how to create brand perception and brand equity using various tools of marketing communication. (Khicha et al, 2012). Providing quality products at nominal prices to customers increases their level of satisfaction (Pradeepa and Pandurangan, 2016).

Brand trust created based on knowledge is different from those based on emotion especially in the case of baby care toiletries (Srivastava \& Dash, 2013). Customers always prefer manufacturer brands to private retail brands owing to the physical risks and financial risks and their perceived performance associated with the latter. The participants of the focus group had only one main issue- Quality. Even though manufacturer brands were priced higher than retail brands, customers were willing to pay a premium price as quality and risk were topping the agenda more than price (Broadbridge and Morgan, 2000).

This study uses latent class modeling (LCM) to explore the effects of channel specific perceptions, along with other variables, on purchase channel intention. Based on results, when LCM is used initially in model exploration, it allows the user to specify a model more intelligently wherein the taste heterogeneity is (potentially) specified deterministically in the end, and it often yields in a more economical model and may even fit the data better. (Tang and Mokhtarian, 2009).

This study aims to craft and test a theory by examining the combinations of causal antecedents for predicting intention to purchase tourism weather insurance (IPTWI) and destination loyalty (Olya and Altinay, 2015).

Baby Products In Indian Context: 
Indian baby care segment is expected to grow at the rate of $13.66 \%$ CAGR in the coming years (Business Wire). Many leading players have made ambitious projections regarding this segment's growth at more than $15 \%$ due to the increased spending per child from INR 6917 to INR 14079 which is at CAGR $12.57 \%$. by 2020 , the total number of babies is going to increase from 127 million to 135 million.

\section{Methodology:}

Now the companies are also developing the products with the latest cutting edge concerning the safety of the product. The retailers are in India are trying to provide the best products to the customers. The customers will look into various factors very seriously when they are purchasing the baby products. They go with the word of mouth; they browse into the website, they see for the product reviews, consumer reports, etc. before purchasing the baby products. This research paper reveals the purchase intention of the baby products and the factors that really influence to purchase the products. The paper shows simulation modelling on the purchase intention of the baby products.

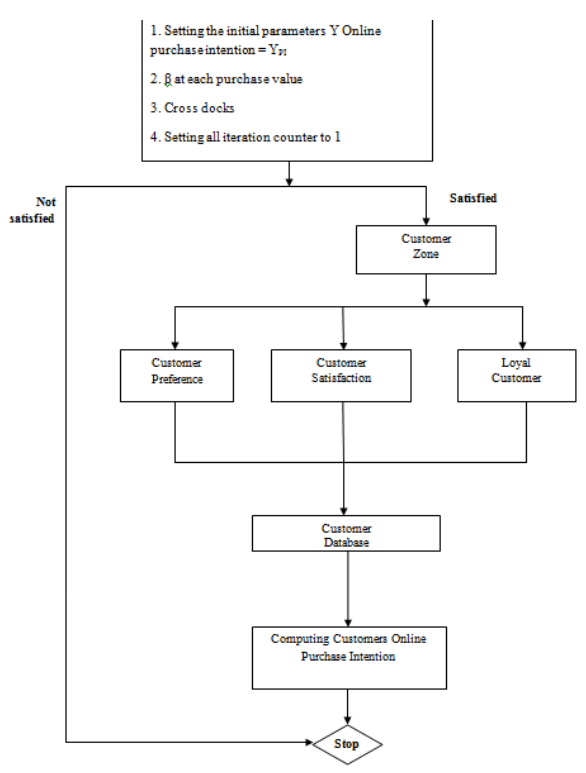

Fig. 1: Linear Programming Models.

Linear Programming Models

Decision variables:

Purchase intention $\left(\mathrm{Y}_{\mathrm{PI}}\right)$; Customer Preference $\left(\mathrm{Y}_{\mathrm{CP}}\right)$; Customer Satisfaction $\left(\mathrm{Y}_{\mathrm{CS}}\right)$; Loyal Customer $\left(\mathrm{Y}_{\mathrm{LC}}\right)$.

Initial constraints helps to develop online purchase intention of baby care products and the major constraints used in our study were customer preference, customer satisfaction and customer loyalty.

Data:

Number of repeated customers $\left(N_{R C}\right)$ :

Number of repeated customers have been taken as sources of data to construct linear programming models for online purchase intention of baby care products in Indian context.

Constraints: $\quad$ Satisfied $\left(D_{\mathrm{S}}\right)$ : $\quad$ Not satisfied $\left(\mathrm{D}_{\mathrm{NS}}\right)$

Satisfied and not satisfied has included as group variables or group constraints.

Customer Preference

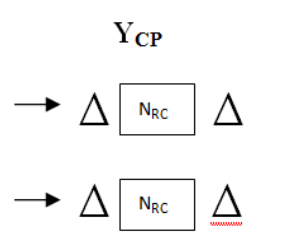

Customer Satisfaction

$\mathrm{Y}_{\mathrm{CS}}$
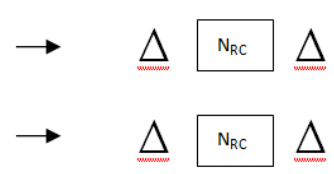

Loyal Customer

$\mathrm{Y}_{\mathrm{LC}}$

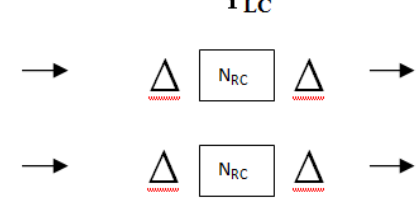

Solution after two major iterations:

LP model for Online purchase intention:

$\mathrm{Y}_{\mathrm{PI}}=\mathrm{Y}_{\mathrm{CP}}+\mathrm{Y}_{\mathrm{CS}}+\mathrm{Y}_{\mathrm{LC}}$

The online purchase intention is combination of customer preference, customer satisfaction and customer loyalty.

Changing Objective Function:

$\mathrm{Y}_{\mathrm{PI}}=\mathrm{Y}_{\mathrm{CP} 1}+\mathrm{Y}_{\mathrm{CP} 2}+\mathrm{Y}_{\mathrm{CP} 3} \ldots \ldots \ldots \ldots \ldots+\mathrm{Y}_{\mathrm{CPN}}$

The above formula helps to develop total customer preference on online purchase intention of baby care products.

$\mathrm{Y}_{\mathrm{PI}}=\mathrm{Y}_{\mathrm{CS} 1}+\mathrm{Y}_{\mathrm{CS} 2}+\mathrm{Y}_{\mathrm{CS} 3} \ldots \ldots \ldots \ldots \ldots+\mathrm{Y}_{\mathrm{CSN}}$

The above formula helps to develop total customer satisfaction on online purchase intention of baby care products.

$\mathrm{Y}_{\mathrm{PI}}=\mathrm{Y}_{\mathrm{LC} 1}+\mathrm{Y}_{\mathrm{LC} 2}+\mathrm{Y}_{\mathrm{LC} 3} \ldots \ldots \ldots \ldots \ldots+\mathrm{Y}_{\mathrm{LCN}}$

The above formula helps to develop total loyal customer on online purchase intention of baby care products.

Optimal solution:

$\mathrm{Y}_{\mathrm{PI}}=\mathrm{Y}_{\mathrm{CPN}}+\mathrm{Y}_{\mathrm{CSN}}+\mathrm{Y}_{\mathrm{LCN}}$

If you lower and upper the objective function or constraint's coefficient of a decision variable, then the modelling does not change. 
What if you increase the number of repeated customers or decision variables coefficient? Naturally, increasing leads impact over online purchase intention of baby care products in Indian context.

$\mathbf{Y}_{\mathbf{P I}} \leq \mathbf{D}_{\mathrm{S}}$

What if you decrease the number of repeated customers or decision variables coefficient? Naturally, decreasing leads impact over online purchase intention of baby care products in Indian context.

\section{$\mathbf{Y}_{\mathbf{P I}} \geq \mathbf{D}_{\mathrm{NS}}$}

Conclusion And Recommendations:

The major aim of this study is to develop linear programming model for online purchase intention of baby care products in Indian context. Now the companies are also developing the products with the latest cutting edge concerning the safety of the product. The retailers are in India are trying to provide the best products to the customers. The customers will look into various factors very seriously when they are purchasing the baby products. They go with the word of mouth; they browse into the website, they see for the product reviews, consumer reports, etc. before purchasing the baby products. This research paper reveals the purchase intention of the baby products and the factors that really influence to purchase the products. The paper shows simulation modelling on the purchase intention of the baby products. Weather, if increase in the number of repeated customers or decision variables coefficient? Naturally, increasing leads impact over online purchase intention of baby care products in Indian context. Weather, if increase in decrease the number of repeated customers or decision variables coefficient? Naturally, decreasing leads impact over online purchase intention of baby care products in Indian context.

\section{REFERENCES}

Yee, C.F., R. Chin, 2007. Parental perception and attitudes on infant feeding practices and baby milk formula in East Malaysia. International journal of consumer studies, 31(4): 363-370. 819.

Mathuthra, O., K. Latha, 2016. Customers attitude towards baby products of Johnson \& Johnson and Himalayan products, Coimbatore city. IJAR, 2(6): 816-

Pradeepa, V., P. Pandurangan, 2016. Mothers' Perception towards the Quality of Baby Food Products in Coimbatore District. Journal of Commerce and Management Thought, 7(1): 122.

Srivastava, N., S.B. Dash, 2013. Antecedents of Brand Trust in the Baby Care Toiletries Product Brands: an Empirical Study in the Indian Context. ACR European Advances.

Broadbridge, A., H.P. Morgan, 2001. Retail-brand baby-products: What do consumers think?. Journal of Brand Management, 8(3): 196-210.

Tang, W.L., P.L. Mokhtarian, 2009. Accounting for taste heterogeneity in purchase channel intention modeling: an example from northern California for book purchases. Journal of Choice Modelling, 2(2): 148-172.

Olya, H.G., L. Altinay, 2016. Asymmetric modeling of intention to purchase tourism weather insurance and loyalty. Journal of Business Research, 69(8): 2791-2800.

Khicha, P.K., N. Benard, Oyagi, 2012. Andrew Nyangau S. Brand Perception on Baby Accessory Products, Kaim Journal of Management and Research, 4(12): $38-42$. 